Article

\title{
Evolution of Policy Concerning the Readjustment of Inefficient Urban Land Use in China Based on a Content Analysis Method
}

\author{
Yang Bai ${ }^{1}{ }^{1}$, Wei Zhou ${ }^{1,2,3, *}$, Yanjun Guan ${ }^{1}$, Xue Li $^{1}$, Baohua Huang ${ }^{4}$, Fengchun Lei ${ }^{4}$, \\ Hong Yang ${ }^{4}$ and Wenmin Huo ${ }^{5}$ \\ 1 School of Land Science and Technology, China University of Geosciences Beijing, Beijing 100083, China; \\ baiyang_bes@cugb.edu.cn (Y.B.); guanyj@cugb.edu.cn (Y.G.); lixue@cugb.edu.cn (X.L.) \\ 2 Key Laboratory of Land Consolidation and Rehabilitation, Ministry of Natural Resources, \\ Beijing 100035, China \\ 3 Technology Innovation Center for Ecological Restoration in Mining Areas, Ministry of Natural Resources, \\ Beijing 100083, China \\ 4 Land Consolidation and Rehabilitation Center, Ministry of Natural Resources, Beijing 100035, China; \\ huangbaohua@lcrc.org.cn (B.H.); leifengchun@lcrc.org.cn (F.L.); yanghong@lcrc.org.cn (H.Y.) \\ 5 Chinese Academy of Natural Resource Economics, Beijing 101149, China; wmhuo@calre.org.cn \\ * Correspondence: zhouw@cugb.edu.cn; Tel.: +86-010-8232-1867
}

Received: 5 November 2019; Accepted: 19 January 2020; Published: 21 January 2020

\begin{abstract}
In a 21st century context characterized by the inefficient use of urban construction land, to optimize land use structure and transform resource utilization methods, it is necessary for the Chinese government to improve land use efficiency. Promoting the readjustment of inefficient urban land use has become essential. The purpose of this paper is to sort through the policies addressing the readjustment of inefficient urban land use in China, identify the promulgation date, longitudinal hierarchy, and horizontal composition of the relevant policies, and summarize the evolutionary trend of such policies. This study aims to provide a reference for the adjustment and improvement of relevant policy systems in China. The content analysis method was used in this study, and NVivo 12 software was used to compare and verify the analysis process. The results show the following: (1) A large number of relevant policies have been promulgated, with a total of 12 items from 1988 to 2012, increasing to six items annually on average from 2013 to 2019. The Communist Party of China Central Committee, the National People's Congress of the People's Republic, the State Council and relevant ministries promulgated $13.46 \%, 11.54 \%, 28.85 \%$, and $46.15 \%$, respectively, of the relevant policies. (2) The existing policies are mostly issued in the form of notices, opinions, management regulations, etc.; therefore, their level of effectiveness is low, and the role of norms is weak. (3) Finally, the policy content experienced stages of initial exploration, basic establishment, and continuous improvement. It also covered aspects such as Standard Control, Market Configuration, Overall Planning, Incentive Mechanisms, Income Distribution, and Supervision Evaluation. The system for policies addressing readjustment of inefficient urban land use has basically been perfected, although post approval supervision still needs to be strengthened. Therefore, the process of readjusting inefficient urban land use should be optimized, new modes of readjustment should be constantly explored, and inefficient land use should be addressed across the entire territory.
\end{abstract}

Keywords: land use; urban land; land readjustment; content analysis method; policy evolution 


\section{Introduction}

Since China's reform and opening up, land use patterns have been based on incremental expansion mainly aimed towards meeting the needs of rapid economic and social development; the demand for urban land is high, and land resources are becoming an increasingly prominent bottleneck [1-5]. The urbanization rate in 1990 was $26.41 \%$, and the built-up area per capita was at its lowest point. Since then, cities have entered a rapid urbanization period. The urbanization rate and built-up area per capita have increased rapidly and are expected to peak in approximately 2020. Specifically, the built-up area per capita in 2014 was 127.02 square meters per person [6,7], showing that with the steady advancement of Chinese urbanization, the previous expansion-type development has proven to be unsustainable, the development mode of incremental planning based on spatial expansion has changed, and urban development planning has gradually shifted from incremental expansion to stock exploration [8-11]. The development model of inventory planning takes urban renewal as its driver, starting by improving public facilities, optimizing the structure of industrial land, accelerating urban transformation, and upgrading infrastructure [12]. It aims to renovate the inefficient stock of construction land in specific built-up areas of the city. This means that urban development is gradually transforming and upgrading from urban sprawl to the readjustment of inefficient urban land use in China [13]. Given the current status of economic and social sustainable development in China, although the planning of urban land still tends toward the expansion of the existing land stock, a higher level of efficiency is required rather than speed. Intensive, scientific, and balanced land use should become the basic criteria in pursuit of efficiency goals in the development model of inventory planning [14]. Land use efficiency means that when people use land resources as factors for production, they continuously improve the level of production technology and rationally allocate the input ratio of each production factor to increase the use level of land resources and maximize the output of land resources $[15,16]$. Inefficient urban land refers to urban construction land that has been identified as construction land by the second national land survey. This land has clear ownership, with no controversies or legal disputes, but also has a scattered layout, extensive and unreasonable use, and dilapidated construction [17]. Combining the Ministry of Natural Resources survey results on the readjustment of inefficient urban land use and relevant data from the National Bureau of Statistics, the area of inefficient urban land accounted for $9.85 \%$ of the urban built-up area in 2018 [18], and land use efficiency was lower. To achieve the goals of maintaining cultivated land, promoting growth, optimizing the land use structure, and transforming resource utilization methods in China, it is necessary to improve land use efficiency [19-23]. Therefore, promoting the readjustment of inefficient urban land use has become a necessary next step.

Due to differences in development time and focus, some countries refer to the readjustment of inefficient urban land use as "urban renewal" [24-34]. Urban renewal mainly arises in developed Western countries [35-40]. The urban renewal development process of European and American countries represented by the United States, the United Kingdom, and France is mainly divided into three stages: (1) From the 1940s to the 1970s, demolition and reconstruction gave way to comprehensive renovation and renewal, and finally to small-scale, organic renewal in phases [41-43]. For example, in the mid-1960s, the Model City Plan of the United States formulated a comprehensive solution to poverty in several specific areas of large cities. Most government subsidies were used to improve education, medical services, employment, and public safety in low-income communities in urban renewal areas, and the remaining subsidies were used to improve infrastructure and living conditions [44]. (2) In the 1980s, urban renewal changed from being led by the government to being led by the market and then to involving multiple parties [45]. For example, the United Kingdom introduced the Planning and Lands Act in 1980, which allows the establishment of urban development zones and enterprise zones and encourages joint-stock companies that cooperate to participate in urban renewal, thereby activating depressed areas of the inner city [46]. (3) Since the 1990s, urban renewal has changed from focusing on the physical environment to being people oriented and promoting sustainable development [47,48]. For example, France promulgated the Social Solidarity and Urban 
Renewal Law in 2000, which established urban renewal as a new urban development model promoting the economical use of space and energy, the rejuvenation of declining urban areas, and the enhancement of social characteristics. Due to differences in socioeconomic environments, urbanization processes, social participation, and coordination mechanisms, the readjustment of inefficient urban land use in coastal areas, such as Guangdong, Zhejiang, Jiangsu, Shanghai, and Hong Kong in China, has certain differences from Western urban renewal. For example, Western urban renewal after the Second World War was based on the rise, development, and maturity of cities. As a whole, it was a process of urban self-healing and improvement. The readjustment of inefficient urban land use in China's coastal areas occurs against the background of increasing urbanization, and the frequent criticisms of this process include that it involves insufficient social participation, weak coordination mechanisms, and increasing readjustment costs. As the development path of Western urban renewal has passed, the readjustment of inefficient urban land use has developed slowly in China, but it has entered a new stage of organic renewal $[49,50]$. In the new stage of development, large-scale expansion has been transformed, with a focus on the high-quality exploration of land use potential and social development inheriting particular historical and cultural contexts [51-56]. For example, the 798 Art District, located in the Chaoyang district of Beijing, used to be the site of the former state-owned 798 factory and other old factories for the electronics industry. The local government mainly carried out the renovation of the old industrial zone by optimizing the spatial environment of the art zone. Ultimately, the 798 Art District, as an organic combination of contemporary art, architectural space, cultural industry, historical context, and urban living, has become a new landmark of urban culture in Beijing.

However, within the reviewed literature, researchers have observed that most Chinese scholars only focus on policies for the readjustment of inefficient urban land use in pilot cities. Considering existing research, this paper aims to address the following questions: (1) How can the policies of readjustment of inefficient urban land use be analyzed from the national level by using the content analysis method? (2) How can we analyze the entire development process of policy for the readjustment of inefficient urban land use by using the content analysis method [57]?

Overall, studies addressing policy evolution for the readjustment of inefficient urban land use based on the national level play a significant role in the adjustment and improvement of related policies. Therefore, the objectives of this study are as follows: (1) Sort the policies on the readjustment of inefficient urban land use introduced at the national level and use the content analysis method to construct a theoretical framework including policy promulgation date, longitudinal hierarchy, and horizontal composition; (2) Identify the analytical categories and carry out reliability and validity assessments to overcome the subjectivity and uncertainty of qualitative research; (3) Encode the analytical categories and quantitatively analyze the status quo and evolution of policy content; and (4) Use NVivo 12 software to compare and verify the rationality of the analysis process from content analysis methods, and that aims to provide reference for the adjustment and improvement of relevant policy system in China. The innovations of this paper are as follows: (1) We used the content analysis method. Because qualitative research has certain levels of subjectivity and uncertainty, we can use content analysis to convert qualitative analysis into quantitative research, thereby overcoming the disadvantages of qualitative research. (2) Few scholars have systematically analyzed the evolution of policy on the readjustment of inefficient urban land use in China from the national level, and we have filled this gap.

Considering the research questions and objectives, this paper uses the content analysis method to analyze the evolution of policies regarding readjustment of inefficient urban land use in China. This paper is organized into four parts. The next section will focus on the research method and analysis processes of this paper. Section 3 presents analyses of the evolution of policy contents and the results in this paper, including reliability and validity assessments and analyses of changes in policy volume and longitudinal and horizontal policy structures, as well as the validation of NVivo 12 software. This paper ends with a conclusion and discussion in Section 4. 


\section{Research Method and Analysis Processes}

\subsection{Content Analysis Method}

The content analysis method was originally applied in the fields of journalism and communication and can be applied to the systematic research of any piece of literature or recorded communication; thus, it is widely used in the social sciences [58]. Through content analysis, documents expressed in linguistic representations rather than quantities are converted into quantities of data by identifying the key information and main features of the target text and describing the analysis results numerically. Based on analysis of the "quantity" of literature content, characteristics that reflect certain essential aspects of the content can be identified and made easy to count, thus overcoming the subjectivity and uncertainty of qualitative research [59]. This method is somewhat subjective in the division of time periods. To reduce the subjective bias of the judges and the resulting influence on the research results, it is necessary to identify the categories and coding rules in the theoretical analysis framework through reliability testing to ensure the scientific rigor of the analysis process and the results. Therefore, it is necessary to select different judges to compare the coding results of the same classification sample, and the consistency of the two must be greater than $80 \%$.

\subsection{Data Source and Sample Selection}

To ensure the orderly readjustment of inefficient urban land use in China, the Communist Party of China (CPC) Central Committee, the National People's Congress (NPC) of the People's Republic, as well as the State Council and its relevant departments have issued a series of rules and regulations and made clear provisions on the overall requirements, incentive mechanisms, and safeguard measures. In this paper, the relevant policies since the reform and opening up are selected as the research data, and the policy documents issued by the abovementioned departmental agencies are used as objective evidence for analyzing the evolution of policies. Through the direct search of official websites, publicly promulgated policies addressing the readjustment of inefficient urban land use are obtained by backtracking and searching for the relevant content in the literature materials and policy texts. To ensure the accuracy and representativeness of the text, the main content or the part of the content that is closely related to the readjustment of inefficient urban land use is selected, and the text is determined to be a legislative document or a normative document, such as a binding regulation, opinion, measure, or notice [60]. In addition, the technical points that have been compiled around the planning of the readjustment of inefficient urban land use are included in the analysis. Ultimately, 52 samples of effective policies at the national level are identified (Table 1). 
Table 1. Policy texts relating to the evolution of the readjustment of inefficient urban land use in China.

\begin{tabular}{|c|c|c|c|c|}
\hline Form & Number & Name of the Policy Text & Brief Summary and Qualitative Judgment of Policy & Date \\
\hline \multirow{6}{*}{$\begin{array}{l}\text { Guidelines of } \\
\text { CPC }\end{array}$} & 1 & $\begin{array}{l}\text { Decision of the Communist Party of China Central Committee } \\
\text { (CCCPC) on Some Major Issues Concerning Comprehensively Deeping } \\
\text { the Reform }\end{array}$ & $\begin{array}{l}\text { Establish space planning system and improve the intensive use of } \\
\text { energy, water, and land. }\end{array}$ & 2013 \\
\hline & 2 & $\begin{array}{l}\text { Recommendations of the CCCPC on the 13th Five-Year Plan for } \\
\text { Economic and Social Development }\end{array}$ & $\begin{array}{l}\text { Adhere to the strictest land-saving system, adjust the structure of } \\
\text { construction land, and promote the readjustment of inefficient urban } \\
\text { land use. }\end{array}$ & 2015 \\
\hline & 3 & $\begin{array}{l}\text { Several Opinions of the CССРC on the Comprehensive Revitalization } \\
\text { of Old Industrial Bases in Northeast China }\end{array}$ & $\begin{array}{l}\text { The central government has continued to increase investment for } \\
\text { shantytown reconstruction and promote urban renewal. }\end{array}$ & 2016 \\
\hline & 4 & $\begin{array}{l}\text { Opinions of the CСCPC on Strengthening the Protection of Cultivated } \\
\text { Land and Improving the Balance of Compensation }\end{array}$ & $\begin{array}{l}\text { Revitalize the stock of construction land and optimize the layout of } \\
\text { construction land. }\end{array}$ & 2017 \\
\hline & 5 & $\begin{array}{l}\text { Guiding Opinions of the CCCPC on Coordinating the Reform of the } \\
\text { Property Right System of Natural Resource Assets }\end{array}$ & $\begin{array}{l}\text { Play a decisive role in allocating resources in the market by improving } \\
\text { the price formation mechanism. }\end{array}$ & 2019 \\
\hline & 6 & $\begin{array}{l}\text { Several Opinions of the CCCPC on Establishing a Territorial Planning } \\
\text { System and Supervising Implementation }\end{array}$ & Optimize the structure and layout of territorial space. & 2019 \\
\hline \multirow[b]{2}{*}{ Related Laws } & 7 & Land Administration Law of the People's Republic of China (PRC) & $\begin{array}{l}\text { Public facilities and other construction land should be rationally } \\
\text { distributed, comprehensively developed, and ancillary. }\end{array}$ & 2004 \\
\hline & 8 & Urban-Rural Planning Law of the PRC & $\begin{array}{l}\text { Reconstruction of old cities should follow the principle of reasonable } \\
\text { layout, and it should protect historical and cultural heritage. }\end{array}$ & 2007 \\
\hline \multirow{8}{*}{$\begin{array}{l}\text { Administrative } \\
\text { Regulations }\end{array}$} & 9 & Tentative Regulations of Urban Land Use Tax of the PRC & $\begin{array}{l}\text { Advocates the rational use of urban land and the adjustment of } \\
\text { land-level income. }\end{array}$ & 1988 \\
\hline & 10 & $\begin{array}{l}\text { Decision of the State Council on Amending the Tentative Regulations } \\
\text { of the Urban Land Use Tax of the PRC }\end{array}$ & $\begin{array}{l}\text { Introduced standards for investigation, identification, disposal, and use } \\
\text { of idle land. }\end{array}$ & 2006 \\
\hline & 11 & $\begin{array}{l}\text { Measures for the Administration of Pilot Projects Linked to the Increase } \\
\text { or Decrease of Urban and Rural Construction Land }\end{array}$ & $\begin{array}{l}\text { Reasonable use of urban land, adjustment of land-level income, } \\
\text { and improvement of land use efficiency. }\end{array}$ & 2008 \\
\hline & 12 & Disposal Methods for Idle Land & $\begin{array}{l}\text { Coordinate the pilot work with planning and guide the structural } \\
\text { adjustment and layout optimization of urban and rural land. }\end{array}$ & 2012 \\
\hline & 13 & Guiding Opinions on Promoting Economical and Intensive Land Use & $\begin{array}{l}\text { Intensive land use refers to the effect of land conservation through scale } \\
\text { guidance, layout optimization, standard control, market allocation, } \\
\text { active utilization, and so on. }\end{array}$ & 2014 \\
\hline & 14 & $\begin{array}{l}\text { Management Measures for the Pilot Project of the Reclamation and } \\
\text { Utilization of Abandoned Industrial and Mining Wasteland }\end{array}$ & $\begin{array}{l}\text { Reasonably adjust layout of construction land, and the competent land } \\
\text { and resources department should regularly check its work. }\end{array}$ & 2015 \\
\hline & 15 & $\begin{array}{l}\text { Measures for the Administration of Annual Plans on the Utilization } \\
\text { of Land }\end{array}$ & $\begin{array}{l}\text { Coordinate stocks and newly added construction land to promote } \\
\text { active utilization of stocks. }\end{array}$ & 2016 \\
\hline & 16 & $\begin{array}{l}\text { Measures for the Administration of the Overall Plan for } \\
\text { Land Utilization }\end{array}$ & $\begin{array}{l}\text { Optimization plan for land use structure, layout, timing arrangements, } \\
\text { and saving for intensive land. }\end{array}$ & 2017 \\
\hline
\end{tabular}


Table 1. Cont

\begin{tabular}{|c|c|c|c|c|}
\hline Form & Number & Name of the Policy Text & Brief Summary and Qualitative Judgment of Policy & Date \\
\hline \multirow{15}{*}{$\begin{array}{l}\text { Notices and } \\
\text { Opinions }\end{array}$} & 17 & $\begin{array}{l}\text { Notice of the State Council on Promoting the Economical and Intensive } \\
\text { Use of Land }\end{array}$ & $\begin{array}{l}\text { Construction land should implement market allocation, control land } \\
\text { use standards, strengthen supervision, and establish an } \\
\text { assessment system. }\end{array}$ & 2008 \\
\hline & 18 & $\begin{array}{l}\text { Guiding Opinions of the State Council on Accelerating the } \\
\text { Development of the Producer Services Industry to Promote the } \\
\text { Adjustment and Upgrading of the Industrial Structure }\end{array}$ & $\begin{array}{l}\text { Encourage the development of productive service industries through } \\
\text { the transformation of inefficient urban land use and adhere to } \\
\text { market leadership. }\end{array}$ & 2014 \\
\hline & 19 & $\begin{array}{l}\text { Several Opinions of the State Council on Deepening the Construction } \\
\text { of New Urbanization }\end{array}$ & $\begin{array}{l}\text { Accelerate the transformation of urban shantytowns, urban villages, } \\
\text { and dilapidated houses and establish an incentive mechanism for the } \\
\text { readjustment of inefficient urban land use. }\end{array}$ & 2016 \\
\hline & 20 & $\begin{array}{l}\text { Notice of the State Council on Printing and Distributing the } 13^{\text {th }} \\
\text { Five-Year Plan to Promote the Equalization of Basic Public Services }\end{array}$ & $\begin{array}{l}\text { Accelerate the transformation of concentrated shantytowns and } \\
\text { urban villages. }\end{array}$ & 2017 \\
\hline & 21 & $\begin{array}{l}\text { Notice of the State Council on Several Measures for Utilizing Foreign } \\
\text { Capital to Promote High-Quality Economic Development }\end{array}$ & $\begin{array}{l}\text { Allow localities to support plant transformation and internal land } \\
\text { consolidation to improve intensive land use. }\end{array}$ & 2018 \\
\hline & 22 & $\begin{array}{l}\text { Opinion of the State Council on Promoting the High-Quality } \\
\text { Development of Innovation and Entrepreneurship to Create an } \\
\text { Upgraded Version of Double Innovation }\end{array}$ & $\begin{array}{l}\text { Promote the readjustment of inefficient urban land use, optimize the } \\
\text { structure of land use, revitalize the stock and idle land for innovation } \\
\text { and entrepreneurship. }\end{array}$ & 2018 \\
\hline & 23 & $\begin{array}{l}\text { Guiding Opinions on Promoting the Relocation and Renovation of Old } \\
\text { Industrial Areas in Urban Areas }\end{array}$ & Promote the transformation of shantytowns in the old industrial areas. & 2014 \\
\hline & 24 & $\begin{array}{l}\text { Several Opinions of the State Council on Promoting the } \\
\text { Transformation, Upgrading and Innovation of National Economic and } \\
\text { Technological Development Zones }\end{array}$ & $\begin{array}{l}\text { Optimize the industrial structure and layout with quality improvement } \\
\text { and efficiency upgrading as the core. }\end{array}$ & 2014 \\
\hline & 25 & $\begin{array}{l}\text { Guiding Opinions on Piloting the Readjustment of Inefficient Urban } \\
\text { Land Use }\end{array}$ & $\begin{array}{l}\text { Ten provinces were identified as pilots for the readjustment of } \\
\text { inefficient urban land use in China. }\end{array}$ & 2013 \\
\hline & 26 & $\begin{array}{l}\text { Notice on the } 2013 \text { Action Plan for the Printing and Development } \\
\text { Insurance Red Line Project }\end{array}$ & $\begin{array}{l}\text { Deploy and carry out pilots readjusting inefficient urban land use to } \\
\text { promote urban renewal. }\end{array}$ & 2013 \\
\hline & 27 & Guiding Opinions on Promoting Land Economical and Intensive Use & $\begin{array}{l}\text { Revitalize the stock land for construction, optimize the layout of land } \\
\text { use, improve the land use control standards, and so on. }\end{array}$ & 2014 \\
\hline & 28 & $\begin{array}{l}\text { Notice on Further Doing a Good Job in Land Service Guarantee for } \\
\text { New Urbanization Construction }\end{array}$ & $\begin{array}{l}\text { Establish an incentive mechanism for the readjustment of inefficient } \\
\text { urban land use to promote the transformation of urban villages. }\end{array}$ & 2016 \\
\hline & 29 & $\begin{array}{l}\text { Guiding Opinions on Implementing the Target of Decreasing the Area } \\
\text { of Construction Land for the 13th Five-Year Plan }\end{array}$ & $\begin{array}{l}\text { Efforts will be made to revitalize the stock of construction land and } \\
\text { promote the market-oriented allocation of land resources. }\end{array}$ & 2016 \\
\hline & 30 & $\begin{array}{l}\text { Guiding Opinions on Deepening the Readjustment of Inefficient Urban } \\
\text { Land Use (Trial) }\end{array}$ & $\begin{array}{l}\text { Adhere to government's guidance, planning first, market orientation, } \\
\text { guided by the situation, public participation, and equal consultation. }\end{array}$ & 2016 \\
\hline & 31 & $\begin{array}{l}\text { Notice on the Publication of the Recommended Catalogue (First Batch) } \\
\text { of Land-Saving Technologies and Modes }\end{array}$ & $\begin{array}{l}\text { Introduce a number of typical cases involving land-saving technologies } \\
\text { and land-saving modes. }\end{array}$ & 2017 \\
\hline
\end{tabular}


Table 1. Cont

\begin{tabular}{|c|c|c|c|c|}
\hline Form & Number & Name of the Policy Text & Brief Summary and Qualitative Judgment of Policy & Date \\
\hline \multirow{9}{*}{$\begin{array}{l}\text { Notices and } \\
\text { Opinions }\end{array}$} & 32 & $\begin{array}{l}\text { Guidance on Strengthening Urban Rehabilitation Work for } \\
\text { Ecological Restoration }\end{array}$ & $\begin{array}{l}\text { Make overall use of funds from various sources to speed up the } \\
\text { renovation of old houses. }\end{array}$ & 2017 \\
\hline & 33 & $\begin{array}{l}\text { Implementation Opinions on Supporting the Industrial Transformation } \\
\text { and Upgrading of Old Industrial Cities and Resource-Based Cities }\end{array}$ & $\begin{array}{l}\text { Support the inclusion of cities where demonstration areas are located in } \\
\text { pilots readjusting inefficient urban land use. }\end{array}$ & 2016 \\
\hline & 34 & $\begin{array}{l}\text { Supporting the Construction of the First Batch of Old Industrial Cities } \\
\text { and Resource-Based Cities for Industrial Transformation } \\
\text { and Upgrading }\end{array}$ & $\begin{array}{l}\text { Establish a sound evaluation and reward incentive mechanism and } \\
\text { dynamic adjustment. }\end{array}$ & 2017 \\
\hline & 35 & $\begin{array}{l}\text { Notice on Printing and Distributing the Promotion Plan for the } \\
\text { Readjustment of Inefficient Urban Land Use }\end{array}$ & $\begin{array}{l}\text { Establish the mechanism for monitoring and evaluation, strengthen } \\
\text { risk assessment, and promote the readjustment of inefficient urban } \\
\text { land use. }\end{array}$ & 2017 \\
\hline & 36 & $\begin{array}{l}\text { Notice on Improving the Mechanism of Increasing Deposits for } \\
\text { Construction Land }\end{array}$ & $\begin{array}{l}\text { Effectively dispose of idle land and encourage active utilization } \\
\text { through legal transfer and cooperative development. }\end{array}$ & 2018 \\
\hline & 37 & $\begin{array}{l}\text { Notice on Further Improving the Retention, Utilization and Renovation } \\
\text { of Existing Urban Buildings }\end{array}$ & $\begin{array}{l}\text { Attach great importance to the preservation, use, and renovation of } \\
\text { existing buildings in the city. }\end{array}$ & 2018 \\
\hline & 38 & $\begin{array}{l}\text { Bulletin on the Evaluation of the Conservation and Intensive Use of } \\
\text { Urban Construction Land }\end{array}$ & $\begin{array}{l}\text { Strictly control the scale of construction land and continuously } \\
\text { optimize the structure of land use. }\end{array}$ & 2018 \\
\hline & 39 & $\begin{array}{l}\text { Bulletin on the Promotion of the Readjustment of Inefficient Urban } \\
\text { Land Use }\end{array}$ & $\begin{array}{l}\text { Optimize land use structure and urban spatial layout, improve the } \\
\text { incentive policy system, and so on. }\end{array}$ & 2018 \\
\hline & 40 & $\begin{array}{l}\text { Notice on the Second Batch of Land-Saving Technologies and Model } \\
\text { Case Collection issued by the Ministry of Natural Resources }\end{array}$ & $\begin{array}{l}\text { Collection of typical cases of readjustment of inefficient urban land use } \\
\text { and active use of stock construction land. }\end{array}$ & 2019 \\
\hline \multirow{11}{*}{$\begin{array}{l}\text { Planning and } \\
\text { Reporting }\end{array}$} & 41 & $\begin{array}{l}\text { 10th Five-Year Plan for National Economic and Social Development of } \\
\text { the PRC (2001-2005) }\end{array}$ & $\begin{array}{l}\text { Promote the adjustment of the old industrial base structure, } \\
\text { optimize the industrial structure and regional layout. }\end{array}$ & 2001 \\
\hline & 42 & $\begin{array}{l}\text { 11th Five-Year Plan for National Economic and Social Development of } \\
\text { the PRC (2006-2010) }\end{array}$ & $\begin{array}{l}\text { Strictly control the increment, revitalize the stock, and control the scale } \\
\text { of conversion of agricultural land to construction land. }\end{array}$ & 2006 \\
\hline & 43 & $\begin{array}{l}\text { 12th Five-Year Plan for National Economic and Social Development of } \\
\text { the PRC (2011-2015) }\end{array}$ & $\begin{array}{l}\text { Revitalize the stock of construction land and optimize the } \\
\text { industrial layout. }\end{array}$ & 2011 \\
\hline & 44 & $\begin{array}{l}\text { 13th Five-Year Plan for National Economic and Social Development of } \\
\text { the PRC (2016-2020) }\end{array}$ & $\begin{array}{l}\text { Promote the comprehensive development and utilization of } \\
\text { aboveground and underground three-dimensional space. }\end{array}$ & 2016 \\
\hline & 45 & Report on the Work of the Government in 2007 & Control increments and revitalize stocks. & 2007 \\
\hline & 46 & Report on the Work of the Government in 2015 & Intensify the transformation of urban shantytowns. & 2015 \\
\hline & 47 & Report on the Work of the Government in 2018 & Promote the renovation of urban villages and old communities. & 2018 \\
\hline & 48 & Outline of the Master Plan for National Land Use (2006-2020) & Actively revitalize stock construction land, and so on. & 2006 \\
\hline & 49 & Plan of National New-Type Urbanization (2014-2020) & Optimize urban structure of spatial and management, and so on. & 2014 \\
\hline & 50 & Plan of National Land Consolidation (2016-2020) & Strengthen overall planning and guidance, and so on. & 2016 \\
\hline & 51 & Outline of Territorial Planning (2016-2030) & Focus on revitalizing the stock of land, and so on. & 2016 \\
\hline $\begin{array}{l}\text { Technical } \\
\text { Regulation }\end{array}$ & 52 & $\begin{array}{l}\text { Key Points for the Preparation of Inefficient Urban Land Use } \\
\text { Redevelopment Planning }\end{array}$ & $\begin{array}{l}\text { Formulate the identification standards for inefficient urban land use } \\
\text { and adhere to layout optimization and benefit sharing. }\end{array}$ & 2017 \\
\hline
\end{tabular}




\subsection{Policy Text Analysis Framework}

After the policy texts concerning the readjustment of inefficient urban land use in China were collected and sorted, the 52 policies were reviewed in regards to three aspects: the promulgation date, longitudinal hierarchy, and horizontal composition of the text (Figure 1). This laid the foundation for the later coding of the policy text. The promulgation date was mainly used to analyze the change in the number of policies issued over time. Longitudinal hierarchy and horizontal composition were used to analyze the structure of the policy subjects and policy texts. The longitudinal hierarchy was based mainly on an analysis of the composition of policies issued by the CPC Central Committee, the NPC of the People's Republic, and the State Council and its related departments. In addition, the quantitative structure was analyzed based on the different policy subjects. The horizontal composition perspective was adopted to analyze the quantitative structure of the policy text form [61].

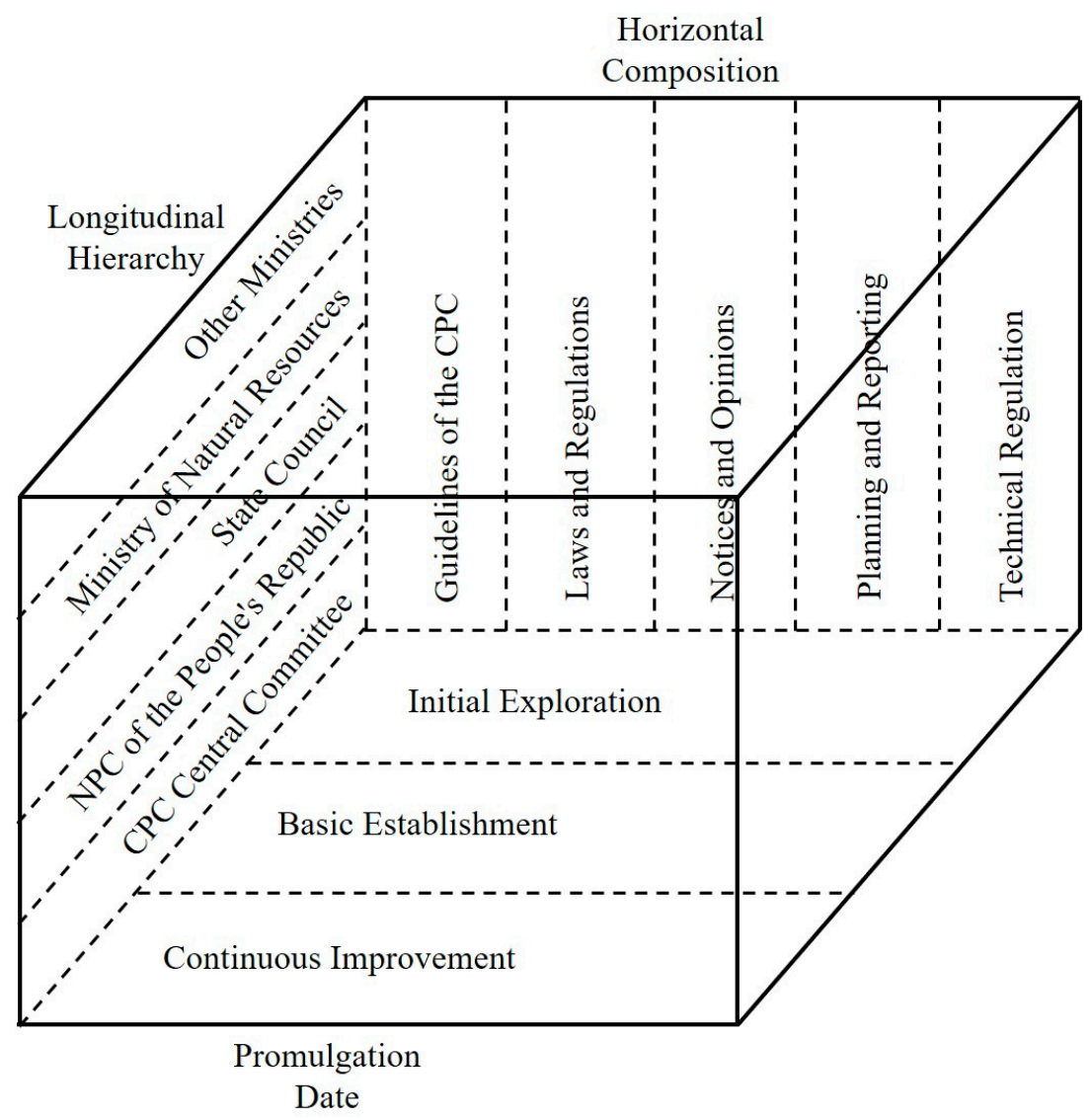

Figure 1. Text analysis framework to capture the policy evolution process.

\subsection{Content Encoding and Frequency Statistics}

Based on a comparative analysis of classification systems used in existing research, the analytical categories were identified according to the research objectives and considering three factors: (1) The analytical categories were based on high-frequency keywords appearing in the policy texts addressing the readjustment of inefficient urban land use. (2) Guided by the research aim, the classification of categories needed to closely follow the evolution of policies for the readjustment of inefficient urban land use. (3) Because some policy texts were not clearly attributable to a specific category, the categories were not mutually exclusive. This meant some policy texts belonged to multiple analytical categories simultaneously. (4) Finally, rather than the general classification system in the field of territorial management, the category system was applicable to the policy texts selected in this paper [62]. After combining the above factors, the analytical categories established in this paper were as follows: A-Update and Renovation; B-Revitalization and Utilization; C-Layout Optimization; 
D-Overall Planning; E-Standard Control; F-Market Configuration; G-Incentive Mechanism; H-Income Distribution; I-Supervised Evaluation; and J-Legal Liability.

After the analytical categories were established, the 52 policy texts were coded according to the "Text Number-Specific Terms/Chapter". If a certain policy text fell into multiple analytical categories, a serial number was assigned in the order of the extracted policy content, following the format of "Text Number-Specific Terms/Chapter - Serial Number", to finally form the code table of the policy content analysis unit. The frequency of the above analytical categories in the three time periods was counted (Table 2), and a two-dimensional distribution map of the policy texts was drawn (Figure 2). In other words, the distribution of policy text content was established in 10 analytical categories over three time periods.

To compare the frequency statistics of the 10 analytical categories, we used NVivo 12 software, which counts the word frequency for each analytical category. We confirmed that the results obtained through NVivo 12 support our frequency statistics.

\begin{tabular}{|c|c|c|c|}
\hline \multirow{2}{*}{$\begin{array}{l}\text { Category } \\
\text { code } \\
\text { J }\end{array}$} & & $13-6$ & $30-5$ \\
\hline & $17-3$ & $13-5 ; 14-2$ & $34-2 ; \quad 35-3$ \\
\hline I & & $25-4 ; 27-6$ & $30-4 ; 52-3$ \\
\hline $\mathrm{H}$ & & $25-3 ; 27-5$ & 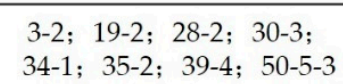 \\
\hline G & $17-2$ & $13-4 ; 18-2 ; 25-2 ; 27-4$ & $5 ; 29-2 ; 30-2$ \\
\hline $\mathrm{F}$ & $9 ; 10 ; 11 ; 17-1$ & $13-3 ; 27-3 ; 49-7$ & $35-1 ; 52-2$ \\
\hline E & $7-59-2 ; 12-2 ; 48-4-4$ & $1 ; 25-1$ & $30-1 ; 39-3 ; 50-5-2 ; 51-6$ \\
\hline $\mathrm{D}$ & $\begin{array}{c}7-59-1 ; 8-1 ; 12-1 ; 41-2-2 \\
43-3 ; 48-4-3\end{array}$ & $\begin{array}{c}2 ; 13-2 ; 14-1 ; 24 ; \\
27-2 ; 49-1\end{array}$ & $\begin{array}{c}4-2 ; 6 ; 16 ; 22-2 ; 31 ; \\
38 ; 39-2 ; 50-1 ; \\
51-1 ; 52-1\end{array}$ \\
\hline $\mathrm{B}$ & $42-6 ; 43-6 ; 45 ; 48-4-2$ & $13-1 ; 27-1$ & $\begin{aligned} & 4-1 ; 15 ; 22-1 ; 29-1 ; 36 ; \\
& 40 ; 44-10 ; 51-4\end{aligned}$ \\
\hline A & $8-3 ; 41-2-1 ; 48-4-1$ & $\begin{array}{c}18-1 ; 23 ; 26 ; \\
46 ; 49-5\end{array}$ & $\begin{array}{c}3-1 ; 19-1 ; 20 ; 21 ; 28-1 ; \\
32 ; 33 ; 37 ; 39-1 ; \\
47 ; 50-5-1\end{array}$ \\
\hline
\end{tabular}

Figure 2. Distribution of policies by form. The capital letters represent different analytical categories, such as A means Update and Renovation, B means Revitalization and Utilization, and so on. The digit in the row of each analytical category represents the number of the policy text within the corresponding analytical category, e.g., the analytical category is the first line number 41-2-1 corresponding to code A, which means that the analytical category is the policy text under Update and Renovation. The number of this policy text is 41 , the specific term/Chapter is 2 , and the serial number is 1 , thus forming the format of "Number-Specific Terms/Chapter-Serial Number". 
Table 2. The frequency and percentage of policy texts.

\begin{tabular}{|c|c|c|c|c|c|c|c|c|c|c|}
\hline \multirow{2}{*}{ Number } & \multirow{2}{*}{ Code } & \multirow{2}{*}{ Analysis Category } & \multicolumn{2}{|c|}{ Before 2013} & \multicolumn{2}{|c|}{ 2013-2015 } & \multicolumn{2}{|c|}{ 2016-2019 } & \multicolumn{2}{|c|}{ Total } \\
\hline & & & Frequency & Percentage/\% & Frequency & Percentage/\% & Frequency & Percentage $/ \%$ & Frequency & Percentage/\% \\
\hline 1 & A & Update and Renovation & 3 & 13.64 & 5 & 17.24 & 11 & 21.57 & 19 & 18.63 \\
\hline 2 & $\mathrm{~B}$ & Revitalization and Utilization & 4 & 18.18 & 2 & 6.90 & 8 & 15.69 & 14 & 13.73 \\
\hline 3 & $\mathrm{C}$ & Layout Optimization & 6 & 27.26 & 6 & 20.68 & 10 & 19.61 & 22 & 21.57 \\
\hline 4 & $\mathrm{D}$ & Overall Planning & 3 & 13.64 & 2 & 6.90 & 4 & 7.84 & 9 & 8.82 \\
\hline 5 & $\mathrm{E}$ & Standard Control & 4 & 18.18 & 3 & 10.34 & 2 & 3.92 & 9 & 8.82 \\
\hline 6 & $\mathrm{~F}$ & Market Configuration & 1 & 4.55 & 4 & 13.79 & 3 & 5.88 & 8 & 7.85 \\
\hline 7 & G & Incentive Mechanism & 0 & 0.00 & 2 & 6.90 & 8 & 15.69 & 10 & 9.80 \\
\hline 8 & $\mathrm{H}$ & Income Distribution & 0 & 0.00 & 2 & 6.90 & 2 & 3.92 & 4 & 3.92 \\
\hline 9 & $\mathrm{I}$ & Supervised Evaluation & 1 & 4.55 & 2 & 6.90 & 2 & 3.92 & 5 & 4.90 \\
\hline 10 & $\mathrm{~J}$ & Legal Liability & 0 & 0.00 & 1 & 3.45 & 1 & 1.96 & 2 & 1.96 \\
\hline & & Total & 22 & $100 \%$ & 29 & $100 \%$ & 51 & $100 \%$ & 102 & $100 \%$ \\
\hline
\end{tabular}




\section{Results Analysis}

\subsection{Reliability and Validity Assessment}

The reliability of the content analysis method, that is, the degree of consistency between the measurement results, includes the reliability of the defined category and the reliability between the judges. In this paper, three professors and two associate professors acted as judges to determine the analytical categories. They all have major achievements in intensive land use, urban-town-village land layout optimization control, land use and sustainable development, which are subjects close to the research scope of the readjustment of inefficient urban land use, and they were selected as judges in line with scientific and reasonable research purposes. The results show that the evaluation panel fully agrees with the analytical categories established in this paper, and according to the principle for the evaluation of interrater reliability adopted in the relevant literature, the obtained reliability is 0.89 , which is within the reasonable interval [0.8,0.9] defined by VINEY [63].

The validity of the content analysis method refers to the extent to which the empirical measurement reflects the true meaning of the concept, including validity of the category and of the analytical framework. In the validity evaluation, five experts were invited to evaluate the degree to which the analytical categories and framework in this paper reflect policy for the readjustment of inefficient urban land use by assigning a value from 0-5 [64]. According to the evaluation results, the validity of the analytical category reached 4.72 , and scores for the effectiveness of the analytical framework were $5,5,5,4$, and 5, which means that the constructed categories and framework fitted the existing policy system well and can be used for analysis.

\subsection{Analysis of Changes in Policy Volume}

Since the reform and opening up process in China, the number of policies for the readjustment of inefficient urban land use has shown an upward trend (Figure 3). Based on a systematic study of 52 related policies, 1988, 2013, and 2016 represent historical turning points in the readjustment of inefficient urban land use in China. Only 12 policy texts covering the readjustment of inefficient urban land use were issued between 1988 and 2012, most of which were laws, regulations, and planning reports. A total of 12 relevant policies were issued during 2013-2015, accounting for 23\% of the total policy texts on the readjustment of inefficient urban land use in China. The number of relevant policies introduced in 2016-2019 increased dramatically, with a total of 28 items and an average of seven items per year, accounting for $54 \%$ of the total policy texts for the readjustment of inefficient urban land use in China; most of these are notices. Over time, inefficient urban land use has become an important issue that cannot be ignored. The Chinese government has successively introduced a number of relevant policies for regulation and guidance.

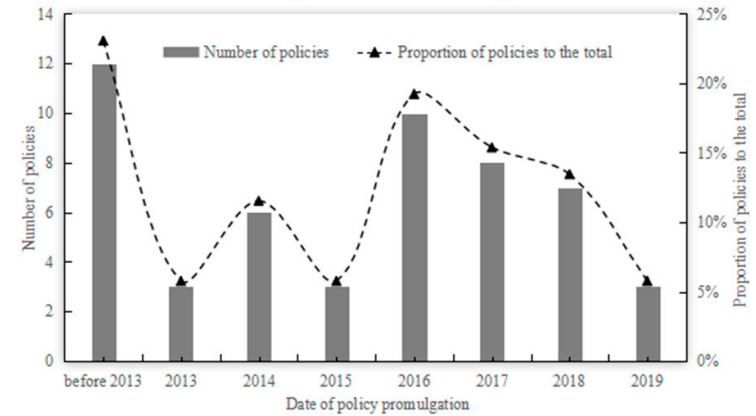

(a)

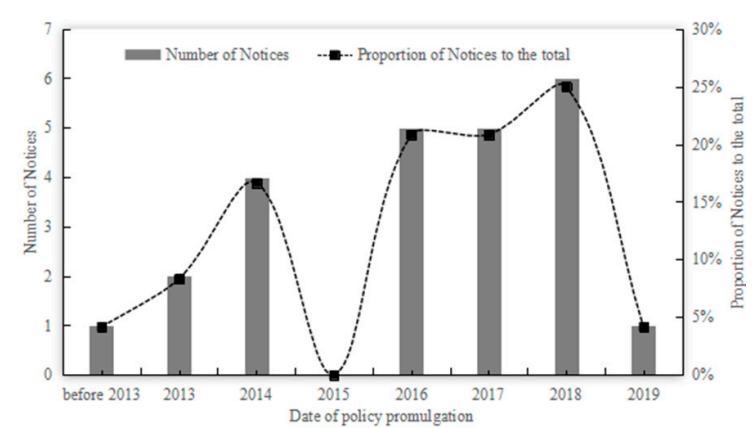

(b)

Figure 3. Changes in the number and proportion of relevant policies: (a): Changes in the number and proportion of total policies; (b): Changes in number and proportion of policies in the form of Notices. 


\subsection{Analysis of the Longitudinal and Horizontal Policy Structure}

The social network analysis function in NVivo 12 software can focus on connections between various social entities. According to the social network analysis (Figure 4), the NPC of the People's Republic and the State Council are important nodes in the relationship. The CPC Central Committee acts as the top designer in the policy-making process in relation to readjustment of inefficient urban land use. Accordingly, a "center-periphery" structure exists among the multi-sector network in China, which has formed the model of readjustment of inefficient urban land use with the CPC Central Committee as the core, the NPC of the People's Republic and the State Council as the central nodes, and the Ministry of Natural Resources and other Ministries as active responders.

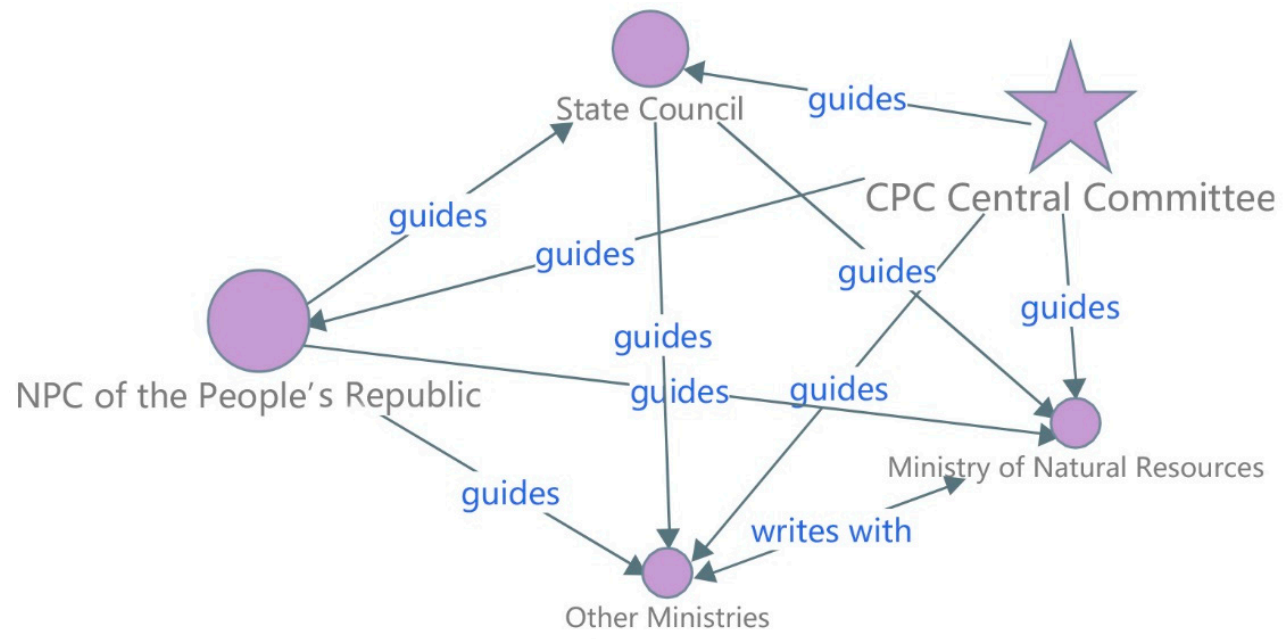

Figure 4. Social network analysis of policy-making entities.

Judging from the composition of the policy-issuing institutions (Table 3), state-level policies for the readjustment of inefficient urban land use are mostly issued by the State Council and its relevant ministries, which have issued $75 \%$ of the total relevant policies in China. In contrast, although the policies issued by the CPC Central Committee and the NPC of the People's Republic are relatively few in number, accounting for only $13.46 \%$ and $11.54 \%$ of the total texts, according to Table 4 , the relevant policy texts emphasize the purpose, process, and enforcement of the readjustment of inefficient urban land use, which shows that the CPC Central Committee attaches great importance to this policy.

Table 3. Composition of policies on the evolution of readjustment of inefficient urban land use.

\begin{tabular}{|c|c|c|c|c|c|c|c|}
\hline \multirow{2}{*}{$\begin{array}{l}\text { Institutional } \\
\text { Composition }\end{array}$} & \multirow{2}{*}{$\begin{array}{c}\text { CPC } \\
\text { Central } \\
\text { Committee }\end{array}$} & \multirow{2}{*}{$\begin{array}{c}\text { NPC of the } \\
\text { People's } \\
\text { Republic }\end{array}$} & \multirow{2}{*}{$\begin{array}{l}\text { State } \\
\text { Council }\end{array}$} & \multicolumn{3}{|c|}{ Relevant Ministers of the State Council } & \multirow[b]{2}{*}{ Total } \\
\hline & & & & Subtotal & $\begin{array}{c}\text { Ministry of } \\
\text { Natural Resources }\end{array}$ & $\begin{array}{c}\text { Other } \\
\text { Ministries }\end{array}$ & \\
\hline Quantity & 7 & 6 & 15 & 24 & 20 & 4 & 52 \\
\hline Percentage/\% & 13.46 & 11.54 & 28.85 & 46.15 & 38.46 & 7.69 & 100 \\
\hline $\begin{array}{c}\text { Text } \\
\text { Composition }\end{array}$ & $\begin{array}{l}\text { Guidelines } \\
\text { of the CPC }\end{array}$ & $\begin{array}{c}\text { Laws and } \\
\text { Regulations }\end{array}$ & $\begin{array}{c}\text { Notices and } \\
\text { Opinions }\end{array}$ & \multicolumn{2}{|c|}{$\begin{array}{l}\text { Planning and } \\
\text { Reporting }\end{array}$} & $\begin{array}{l}\text { Technical } \\
\text { Regulation }\end{array}$ & Total \\
\hline Quantity & 6 & 10 & 24 & \multicolumn{2}{|c|}{11} & 1 & 52 \\
\hline Percentage $/ \%$ & 11.54 & 19.23 & 46.16 & \multicolumn{2}{|c|}{21.15} & 1.92 & 100 \\
\hline
\end{tabular}

In addition, among the policies issued by the relevant ministries of the State Council, the Ministry of Natural Resources issued 20 items, and the other four were issued by other ministries of the State Council. Combining the purpose, process, and enforcement of policy-issuing institutions (Table 4), it can be seen that the readjustment of inefficient urban land use has shown a good form of multisectoral co-management in China. 
Based on the horizontal compositions of policies (Table 3), policies regarding readjustment of inefficient urban land use are mainly guided by a large number of "notices" and "opinions" under the laws, regulations, and guidelines of the CPC. In addition, a relatively specific management method has been formulated to control the readjustment of inefficient urban land use. However, the policies were mostly issued in the form of notices, opinions, and management methods, which have a low level of effectiveness.

Table 4. Purpose, process, and enforcement of policy-issuing institutions.

\begin{tabular}{|c|c|c|c|}
\hline $\begin{array}{l}\text { Institutional } \\
\text { Composition }\end{array}$ & Work Purpose & Work Process & Enforcement of Policies \\
\hline $\begin{array}{l}\text { CPC Central } \\
\text { Committee }\end{array}$ & $\begin{array}{l}\text { Implement major livelihood projects } \\
\text { in full such as shantytown } \\
\text { reconstruction, and promote urban } \\
\text { renewal and equalization of } \\
\text { urban-rural public services. }\end{array}$ & $\begin{array}{l}\text { Central finance continued to } \\
\text { increase its support for shantytown } \\
\text { reconstruction and encouraged the } \\
\text { National Development Bank and } \\
\text { others to strengthen } \\
\text { financial support. }\end{array}$ & $\begin{array}{l}\text { Explored effective models for } \\
\text { policy-based, developmental, } \\
\text { and commercial financial } \\
\text { institutions to support the } \\
\text { readjustment of inefficient urban } \\
\text { land use. }\end{array}$ \\
\hline State Council & $\begin{array}{l}\text { Based on the second land survey, } \\
\text { evaluate the utilization and the } \\
\text { input-output situation of existing } \\
\text { construction land and deal with } \\
\text { existing problems in the utilization } \\
\text { of construction land in accordance } \\
\text { with laws and regulations. }\end{array}$ & $\begin{array}{l}\text { Improve the supply method in the } \\
\text { process of urban land readjustment; } \\
\text { encourage former state-owned land } \\
\text { users carry out renovation } \\
\text { and readjustment. }\end{array}$ & $\begin{array}{l}\text { If the land has been idle for more } \\
\text { than one year and less than two } \\
\text { years, the idle land fee will be levied } \\
\text { at } 20 \% \text { of the land transfer price. }\end{array}$ \\
\hline $\begin{array}{l}\text { Ministry of } \\
\text { Natural } \\
\text { Resources }\end{array}$ & $\begin{array}{l}\text { Carry out pilots for the } \\
\text { readjustment of inefficient urban } \\
\text { land use, revitalize low-efficiency } \\
\text { urban land, increase the effective } \\
\text { supply of urban construction land, } \\
\text { and improve the ability of land to } \\
\text { sustain economic and } \\
\text { social development. }\end{array}$ & $\begin{array}{l}\text { Identify } 10 \text { provinces including } \\
\text { Inner Mongolia, Liaoning, Shanghai, } \\
\text { Jiangsu, Zhejiang, Fujian, Jiangxi, } \\
\text { Hubei, Sichuan, and Shaanxi to } \\
\text { carry out pilot projects for } \\
\text { readjustment of inefficient urban } \\
\text { land use. }\end{array}$ & $\begin{array}{l}\text { Improved incentive mechanism for } \\
\text { the readjustment of inefficient urban } \\
\text { land use, such as encouraging } \\
\text { industrial transformation and } \\
\text { upgrading to optimize the structure } \\
\text { of land use. }\end{array}$ \\
\hline Other Ministries & $\begin{array}{l}\text { Encourage small-scale and gradual } \\
\text { renewal of old urban areas to } \\
\text { protect the city's traditional pattern } \\
\text { and texture. }\end{array}$ & $\begin{array}{l}\text { Comprehensive use of } \\
\text { energy-saving transformation and } \\
\text { other aspects of funds to accelerate } \\
\text { the renovation of old communities. }\end{array}$ & $\begin{array}{l}\text { Support the installation of elevators } \\
\text { in old buildings that meet } \\
\text { requirements to improve the } \\
\text { building's use function } \\
\text { and livability. }\end{array}$ \\
\hline
\end{tabular}

A comparison of the horizontal and longitudinal composition of the policies shows that although the current policies for the readjustment of inefficient urban land use are not as clear as the policies for cultivated land protection and land use control in the Land Administration Law, a number of relevant policies have been jointly developed and promulgated by various departments such as the Ministry of Natural Resources. From an overall perspective, the frequency of joint promulgation reflects that the policies adopted by various management departments are based on system management considerations, and the coordination of relevant policies issued by various authorities will become the key to their smooth implementation.

\subsection{Evolutionary Analysis of Policy Content}

Based on the frequency of the promulgation of policies for the readjustment of inefficient urban land use in China (Table 2), the policy content presents an evolutionary trend from initial exploration to basic establishment and finally to continuous development, accompanied by the continuous enrichment of policy content and the increasing distribution of policies across the 10 categories (Figure 2).

\subsubsection{Stage of Initial Exploration}

Before 2013, the readjustment of inefficient urban land use was in the stage of initial exploration in China. The reform and open-up started in 1978, and China entered a development track characterized 
by urbanization. Due to its focus on economic construction, the Chinese government ignored the shortcomings of rapid urban expansion and did not pay attention to the readjustment of inefficient urban land use. By the time of the promulgation and implementation of the Tentative Regulations of Urban Land Use Tax of the PRC in 1988, the Chinese government had gradually realized that urban construction land should follow the path of sustainable development. This regulation advocates the rational use of urban land, the adjustment of land-level income, the improvement of land use efficiency, and the strengthening of land management. In 2007, the Urban-Rural Planning Law of the PRC marks the first time that the Chinese government has clarified the principle of "reconstruction of the old city" in the form of law. In 2008, the Outline of the Master Plan for National Land Use (2006-2020) was issued. This master plan for land use was a top-level design to improve the readjustment of inefficient urban land use in China, and it marks entrance into a nascent stage. With the release of the 12th Five-Year Plan for National Economic and Social Development of the PRC (2011-2015) in 2011, the Chinese government was gradually turning its attention to the problem of economical and intensive land use. This laid a preliminary foundation for the readjustment of inefficient urban land use. The above policies did not directly address the readjustment of inefficient urban land use, but they clearly marked the beginning of the exploration of mechanisms for the readjustment of inefficient urban land use in China.

\subsubsection{Stage of Basic Establishment}

The period 2013-2015 was a stage characterized by the basic establishment of policy for the readjustment of inefficient urban land use in China. The promulgation and implementation of the Guiding Opinions on Piloting the Readjustment of Inefficient Urban Land Use in 2013 marked the formal establishment of the pilot project for the readjustment of inefficient urban land use in China. In 2014, the Guiding Opinions on Promoting the Relocation and Renovation of Old Industrial Areas in Urban Areas marked China's entrance into the climax stage of the "renovation of shantytowns". A series of issues such as extensive land use brought about by "shantytowns" drew great attention from the Chinese government $[65,66]$. In 2014, the promulgation of Guiding Opinions on Promoting Economical and Intensive Land Use signified that the Chinese government had standardized and guided the readjustment of inefficient urban land use at the institutional level. Subsequently, the Chinese government introduced a series of related policies until the promulgation of Recommendations of the CCCPC on the 13th Five-Year Plan for Economic and Social Development (2015), which marked the basic establishment of a policy system for the readjustment of inefficient urban land use in China. At this stage, the relevant policy system was initially constructed around the issues of Update and Renovation, Layout Optimization, Standard Control, and Market Configuration.

The two-dimensional map of the policy text (Figure 2) shows that the policies initially referring to only Layout Optimization, Revitalization and Utilization, Update and Renovation, Overall Planning and Standard Control evolve to include Update and Renovation, Layout Optimization, Standard Control, Market Configuration, Revitalization and Utilization, Overall Planning, Incentive Mechanism, Income Distribution, and Supervised Evaluation. In particular, the number of policies on the subject of market configuration increases significantly, accounting for $9.24 \%$ of the total. Moreover, themes such as Incentive Mechanism and Income Distribution continue to deepen, accounting for $6.9 \%$, which indicates that the Chinese government is paying increasingly more attention to incentives and fairness in the readjustment of inefficient urban land use.

\subsubsection{Stage of Continuous Improvement}

In 2016-2019, the readjustment of inefficient urban land use in China was in the stage of continuous development. In 2016, under the Guiding Opinions on Deepening the Readjustment of Inefficient Urban Land Use (Trial), the Chinese government adhered to the principles of "government guidance, planning first", "market orientation, guided by the situation", and "public participation, equal consultation" [67]. This clarifies the scope of readjustment, promotes the investigation of inefficient urban land use and 
the construction of the map, and further strengthens planning coordination and implementation. These guiding opinions mark the entry of the readjustment of inefficient urban land use into a new stage of development and improvement in China. In 2017, the Notice on Printing and Distributing the Promotion Plan for the Readjustment of Inefficient Urban Land Use (2017-2018) focused on establishing a mechanism for monitoring and evaluation, strengthening risk assessment, and promoting the readjustment of inefficient urban land use. Subsequently, the Key Points for the Preparation of Inefficient Urban Land Redevelopment Planning marked the first time a policy for the readjustment of inefficient urban land use planning was presented in the form of technical regulations in China.

In 2019, with the promulgation of the Several Opinions on Establishing a Territorial Planning System and Supervising Implementation, the Chinese government insisted on optimizing the spatial structure and layout of the territory, coordinating the comprehensive utilization of aboveground and underground space, and focusing on improving infrastructure and public service facilities, such as transportation and water conservancy. To promote the readjustment of inefficient urban land use under the new normal in China, the Ministry of Natural Resources issued the Notice on the Second Batch of Land-Saving Technologies and Model Case Collection, seeking typical cases of the readjustment of inefficient urban land use, stock construction and utilization, etc. This policy provides guidance for the development and improvement of the readjustment of inefficient urban land use in China.

The number of policy texts continues to increase, and the content is constantly enriched at this stage. In terms of the two-dimensional distribution of policy texts (Figure 2), 50\% of the 10 total keywords are used, and the number of policy texts with the themes of Incentive Mechanism, Revitalization and Utilization and Update and Renovation has increased significantly since the previous stage, with increases of $8.79 \%, 8.79 \%$, and $4.33 \%$, respectively. Therefore, the readjustment of inefficient urban land use is clearly in the stage of continuous improvement in China. This means that under reasonable overall planning, the stock of construction land is revitalized, the incentive mechanism is optimized, and inefficiently used urban land is transformed and readjusted.

\section{Conclusions and Discussion}

In this study, our aim was to explore the evolution of policies concerning readjustment of inefficient urban land use in China and to provide a reference for adjustment and improvement of related policies. From the above results, the readjustment of inefficient urban land use has evolved from initial exploration to basic establishment and finally to continuous improvement. Although policies regarding readjustment of inefficient urban land use have gradually matured in China, opportunities for improvement and development remain in terms of Income Distribution, Supervised Evaluation, and Legal Liability. Considering the research questions proposed at the beginning of this article, we summarized the research results with respect to the theoretical framework, the evolution of policy contents, and theoretical contributions.

\subsection{Changes in Policy Volume}

Along with the rapid development of urbanization and industrialization, several relevant policies for readjustment of inefficient urban land use have been introduced to address the current situation of inefficient use of urban construction land in China. Throughout the evolution of relevant policies, although the Chinese government has actively implemented policies at the national level, many weaknesses remain compared with the urban renewal policies of European and American countries. Therefore, the Chinese government should further improve policies concerning readjustment of inefficient urban land use.

In terms of the time dimension, the number of relevant policies is increasing, from a total of 12 items between 1988 and 2012 to an annual average of 6 items between 2013 and 2019. Although the annual average number of relevant policies is increasing, a certain gap remains compared with the number of urban renewal policies in European and American countries, and many reasons may account for this gap. For example, judging from the social and urban development processes in China, 
the United States, and Britain (Table 5), due to differences in the socio-economic environments in these countries, the development levels of related policies have differed. In the United States and Britain, the role of long-term market economic directly promotes the rapid development of cities. With the formulation and implementation of urban renewal policies, considerable changes have occurred in the urban environment in terms of the layout and spatial structure, and the problem of "urban disease" has been alleviated to varying degrees. However, throughout its 40 years of reform and expansion, China has experienced the entire modernization process carried out by Western developed countries. Urbanization is developing very quickly, but many problems related to inefficient land use remain. Accordingly, the Chinese government has continually promulgated policies for readjustment of inefficient urban land use to solve such problems. Although the urban spatial layout has improved, a considerable amount of work is still required [68,69].

Table 5. Comparison of relevant working environments in China, the United States, and Britain.

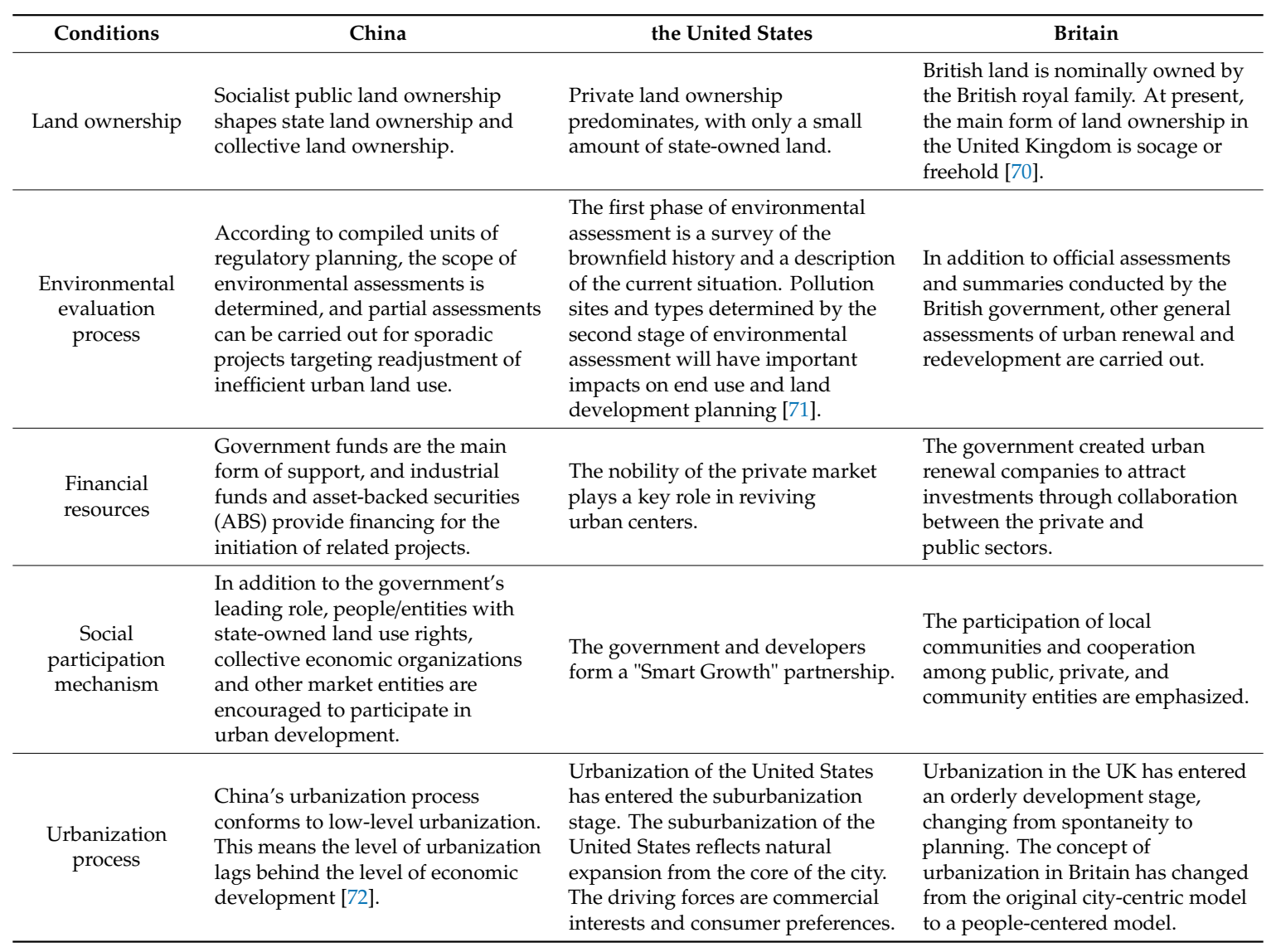

\subsection{Longitudinal and Horizontal Policy Structures}

In terms of the policy-promulgating agencies, the number of policies promulgated by the CPC Central Committee, the NPC of the People's Republic, the State Council, and relevant ministries account for $13.46 \%, 11.54 \%, 28.85 \%$, and $46.15 \%$ of all policies, respectively. Overall, the CPC Central Committee and the NPC of the People's Republic have played vital roles in formulating policies for readjustment of inefficient urban land use in China. In response to the call of the CPC Central Committee and the NPC of the People's Republic, the State Council, the Ministry of Natural Resources, and other ministries have actively engaged in readjustment of inefficient urban land use. Because the work is mainly government-oriented, the degree of social participation is not very high compared with that in European and American countries. Urban renewal in America and Britain (Table 5), the idea of cooperation and participation among the government, private sectors and the community have been widely accepted by residents. A long-term model of urban renewal characterized by cooperation among 
the government, private sectors, and the community has been established, which has promoted the virtuous cycle of urban renewal in a market-oriented environment. However, in China, readjustment of inefficient urban land use is driven by the government. Relevant laws and regulations are imperfect, and social participation is insufficient. Related work still focuses on the pursuit of economic returns and lacks a comprehensive and integrated concept of urban development.

In terms of the policy text form, the existing policies are mostly issued in the form of Notices and Opinions. The number of relevant policies issued in the form of Guidelines of the CPC central committee, Laws, and Regulations is relatively small. This phenomenon is mainly due to the hierarchical system of Chinese government agencies. The CPC Central Committee issues guiding documents, the NPC of the People's Republic formulates and revises relevant laws, the State Council formulates and revises administrative regulations and manages various ministries according to relevant laws, and the Ministry of Natural Resources and other ministries are agencies of policy refinement and enforcement. It is not difficult to see that with the higher level of institutions, the policies number of the readjustment of inefficient urban land use issued by relevant institutions is getting smaller. Therefore, the level of effectiveness of related work is low, and the normative role is not strong.

The current system of urban management in China is flawed and lacks reasonable institutional policies for support and guidance. Too many management agencies have seriously affected communication between the government and enterprises, which has impacted the progress of the readjustment of inefficient urban land use in China. Therefore, the Chinese government should optimize the design of the top-level system and accelerate system legislation for relevant work, especially system legislation for local governments, to strengthen and regulate policy guidance among local governments.

\subsection{Evolution of Related Policies and Contents}

The readjustment of inefficient urban land use has evolved from initial exploration to basic establishment and finally to continuous improvement in China. On the whole, the policy content has basically been improved, with themes such as Standard Control, Market Configuration, Overall Planning, Incentive Mechanisms, Income Distribution, and Supervised Evaluation. According to the analysis of the above results, the Chinese government has increasingly focused on issues related to the Incentive Mechanisms and Market Configuration of related work. Such work addresses inefficient urban land use readjustment mainly through land rent, price leverage, taxation, planning adjustments, land reserves, and other methods of market allocation [73]. Although policies regarding readjustment of inefficient urban land use have gradually matured in China, opportunities for exploration and development remain in terms of Income Distribution, Supervised Evaluation, and Legal Liability. Accordingly, the Chinese government should promulgate as many policy texts oriented toward specific aspects of implementation as possible, especially from the perspectives of Income Distribution, Supervised Evaluation, and Legal Liability, such as technical regulations, to strengthen measures for policy implementation and to ensure smooth progress in the readjustment of inefficient urban land use. In addition, in terms of management agencies, this paper describes the evolution from centralized management of the Ministry of Natural Resources to cooperative management of this ministry by several entities, reflecting the joint responsibility of multiple sectors for the readjustment of inefficient urban land use in China [74-76].

Existing policies mainly target state-owned construction land, and a standard system integrating Standard Control, Market Configuration, and Incentive Mechanisms has been formed. In the context of current territorial planning in China, to create new value and revitalize space, attention will be directed toward inefficiently used land and stock land across the entire territorial space.

\subsection{Theoretical Contributions, Method Limitations, and Directions of Further Research}

This paper fundamentally contributes to systematic analyses of the evolution of policies concerning the readjustment of inefficient urban land use in China and uses a research method combining 
quantitative and qualitative approaches. This paper used the content analysis method to build a theoretical analysis framework based on promulgation dates, the longitudinal hierarchy and the horizontal compositions of policies, identify analytical categories, and analyze the status quo and evolution of policy contents based on quantitative analysis, thus overcoming the subjectivity and uncertainty of qualitative research to a certain extent. Combined with NVivo 12 qualitative analysis software, we obtained empirical conclusions through statistical analysis of word frequencies, social network analysis and other analytical methods, compared and verified the results obtained by the content analysis method, and provided new insight into current policies through systematic analysis of the evolution of policies concerning the readjustment of inefficient urban land use in China.

This paper mainly uses the content analysis method to analyze the evolution of policy concerning the readjustment of inefficient urban land use in China. Although this method can transform qualitative analysis into quantitative research, there are still some limitations. For example, during the formulation of the theoretical framework, the entire development process of the policy can be divided into multiple stages based on the promulgation date. Although the division of the time period is mainly determined by combining the knowledge of relevant experts, this process is somewhat subjective and uncertain.

Further research directions are suggested to improve analysis of the effectiveness of the policy, to resolve the limitations of the content analysis method, and to further improve the ability to carry out quantitative research in this field to effectively assess the policies for the readjustment of inefficient urban land use.

Author Contributions: Y.B. and Y.G. conceived of and designed the research; Y.B. and X.L. made substantial contributions to the design, data processing, and analysis; W.Z. and W.H. critically revised the paper; Y.B. and B.H. contributed to data processing and analysis; F.L. and H.Y. contributed the original data; Y.B. wrote the paper; and W.Z. gave valuable suggestions for the revision of the paper. All authors read and approved the final manuscript.

Funding: This research received no external funding.

Acknowledgments: We sincerely thank the Land Consolidation and Rehabilitation Center of the Ministry of Natural Resources for supplying the research data and the anonymous reviewers and editors for offering valuable comments.

Conflicts of Interest: The authors declare no conflicts of interest.

\section{References}

1. Li, W.; Wang, D.; Li, H.; Wang, J.; Zhu, Y.; Yang, Y. Quantifying the spatial arrangement of underutilized land in a rapidly urbanized rust belt city: The case of Changchun City. Land Use Policy 2019, 83, 113-123. [CrossRef]

2. Chen, L.; Ren, C.; Zhang, B.; Wang, Z.; Liu, M. Quantifying urban land sprawl and its driving forces in Northeast China from 1990 to 2015. Sustainability 2018, 10, 188. [CrossRef]

3. Chen, Y.; Chen, Z.G.; Xu, G.L.; Tian, Z.Q. Built-up land efficiency in urban China: Insights from the General Land Use Plan (2006-2020). Habitat Int. 2016, 51, 31-38. [CrossRef]

4. Lu, S.S.; Guan, X.L.; He, C.; Zhang, J.L. Spatio-temporal patterns and policy implications of urban land expansion in metropolitan areas: A case study of Wuhan urban agglomeration, central China. Sustainability 2014, 6, 4723-4748. [CrossRef]

5. Wang, W.; Wang, Y.; Fan, Z.Y. Study on the Potential Evaluation of Intensive Urban Land Utilization: A Case Study of Harbin City; American Society Civil Engineers: New York, NY, USA, 2015; pp. 477-483.

6. Zhao, M.; Li, X.; Wang, H. Predicting the consumption of construction land for China's urbanization process. China Popul. Resour. Environ. 2016, 26, 405-409. (In Chinese)

7. Liu, X.; Zhang, D.; Chen, B. Characteristics of China's town-level land use in rapid urbanization stage. Acta Geogr. Sin. 2008, 63, 301-310. (In Chinese)

8. Ge, T.; Yang, J.; Hou, W. Urban renewal design based on inventory planning: A case study of Zhengzhou Jingguang road area. City Plan. Rev. 2017, 41, 62-71. (In Chinese)

9. Zhang, B.; Yu, S.; Cheng, L.; Lian, Z. Built-up area regulatory planning compilation: Chanba ecological a district case. Planners 2015, 31, 43-48. (In Chinese) 
10. Chen, C.; Chen, J. Detailed formulation of stock regulatory planning: Foshan practice. Planners 2018, 34, 120-125. (In Chinese)

11. Liu, Y.; Cai, E.; Jing, Y.; Gong, J.; Wang, Z. Analyzing the decoupling between rural-to-urban migrants and urban land expansion in Hubei province, China. Sustainability 2018, 10, 345. [CrossRef]

12. Zou, B. From physical expansion to built-up area improvement: Shenzhen master plan transition forces and paths. Planners 2013, 29, 5-10. (In Chinese)

13. Lu, L.; Guo, H.; Corbane, C.; Li, Q. Urban sprawl in provincial capital cities in China: Evidence from multi-temporal urban land products using Landsat data. Sci. Bull. 2019, 64, 955-957. [CrossRef]

14. Chen, H.; Wang, X.; Guo, Z. The transition of China's urban planning: Thoughts on increment planning, inventory planning and reduction planning. Mod. Urban Res. 2015, 7, 44-48. (In Chinese)

15. Huang, Z.J.; He, C.F.; Zhu, S.J. Do China's economic development zones improve land use efficiency? The effects of selection, factor accumulation and agglomeration. Landsc. Urban Plan. 2017, 162, $145-156$. (In Chinese) [CrossRef]

16. Zhao, X. Econometric Analysis of China's Total Factor Land Use Efficiency. Ph.D. Thesis, Liaoning University, Shenyang, China, 2013. (In Chinese).

17. Nie, L. On Construction Land Utilization Efficiency of Different Types of Cities. Ph.D. Thesis, Nanjing Agricultural University, Nanjing, China, 2017. (In Chinese).

18. Statistics, N.B.O. China Statistical Yearbook in 2018, 1st ed.; China Statistics Press: Beijing, China, $2019 ;$ p. 253.

19. Zhang, Z.; Tan, R.; Wu, C.; Wang, Q.; Xu, S. The practical dilemma and institutional improvement of land readjustment: An empirical study from Shenzhen city. China Land Sci. 2012, 26, 41-47. (In Chinese)

20. Liu, X.; Yan, J.; Wang, Q. Practical dilemma and rational choice of underused urban land readjustment in China. China Land Sci. 2015, 29, 48-54. (In Chinese)

21. Lu, Z.; Wang, H.; Liu, G.; Liang, Y.; Yi, L.; Yang, L.; Cai, C. The spatial reconstruction of inefficient land redevelopment under ecological-economic competition and cooperation: A case study of urban district in Zhanjiang. China Land Sci. 2018, 32, 34-41. (In Chinese)

22. Yao, Z.; Tian, L. Difficulties in redeveloping collective-owned construction land in the background of three olds reconstruction policy: From the perspective of institutional supply-institutional failuer. City Plan. Rev. 2018, 42, 45-53. (In Chinese)

23. Zhang, P.; Zhang, X.; Liu, Y.; Ye, Y.; Hu, Y.; Wu, C. Diversity of urban spatial efficiency based on the land development intensity in Changchun city. Sci. Geogr. Sin. 2018, 38, 895-902. (In Chinese)

24. Zheng, H.W.; Shen, G.Q.; Wang, H. A review of recent studies on sustainable urban renewal. Habitat Int. 2014, 41, 272-279. [CrossRef]

25. Couch, C.; Sykes, O.; Boerstinghaus, W. Thirty years of urban regeneration in Britain, Germany and France: The importance of context and path dependency. Prog. Plan. 2011, 75, 1-52. [CrossRef]

26. Ercan, M.A. Challenges and conflicts in achieving sustainable communities in historic neighbourhoods of Istanbul. Habitat Int. 2011, 35, 295-306. [CrossRef]

27. Holtslag-Broekhof, S. Urban land readjustment: Necessary for effective urban renewal? Analysing the Dutch quest for new legislation. Land Use Policy 2018, 77, 821-828. [CrossRef]

28. Karaman, O. Urban renewal in istanbul: Reconfigured spaces, robotic lives. Int. J. Urban Reg. Res. 2013, 37, 715-733. [CrossRef]

29. Kovacs, Z.; Wiessner, R.; Zischner, R. Urban renewal in the inner city of Budapest: Gentrification from a post-socialist perspective. Urban Stud. 2013, 50, 22-38. [CrossRef]

30. Greene, M.; Mora, R.I.; Figueroa, C.; Waintrub, N.; Ortuzar, J.D.D. Towards a sustainable city: Applying urban renewal incentives according to the social and urban characteristics of the area. Habitat Int. 2017, 68, 15-23. [CrossRef]

31. van der Krabben, E.; Lenferink, S. The introduction of urban land readjustment legislation as an institutional innovation in Dutch land policy. Habitat Int. 2018, 75, 114-121. [CrossRef]

32. Almeida, J.; Ferreira, J.A.; Condessa, B.; Tome, R. Improving land readjustment practice. Application of management models to Portugal. Eur. Plan. Stud. 2018, 26, 1431-1449. [CrossRef]

33. Abe, S.; Nakagawa, D.; Matsunaka, R.; Oba, T. Study on the factors to transform underused land focusing on the influence of railway stations in central areas of Japanese Local cities. Land Use Policy 2014, 41, 344-356. [CrossRef] 
34. Ardiwijaya, V.S.; Sumardi, T.P.; Suganda, E.; Temenggung, Y.A. Rejuvenating idle land to sustainable urban form: Case study of Bandung metropolitan area, Indonesia. Procedia Environ. Sci. 2015, 28, 176-184. [CrossRef]

35. Sacco, P.L.; Ghirardi, S.; Tartari, M.; Trimarchi, M. Two versions of heterotopia: The role of art practices in participative urban renewal processes. Cities 2019, 89, 199-208. [CrossRef]

36. Ahlfeldt, G.M.; Maennig, W.; Richter, F.J. Urban renewal after the Berlin Wall: A place-based policy evaluation. J. Econ. Geogr. 2017, 17, 129-156. [CrossRef]

37. Bacque, M.-H.; Biewener, C. Different manifestations of the concept of empowerment: The politics of urban renewal in the United States and the United Kingdom. Int. J. Urban Reg. Res. 2013, 37, 2198-2213. [CrossRef]

38. Weingaertner, C.; Barber, A.R.G. Urban regeneration and socio-economic sustainability: A role for established small food outlets. Eur. Plan. Stud. 2010, 18, 1653-1674. [CrossRef]

39. Turcu, C. Local experiences of urban sustainability: Researching Housing Market Renewal interventions in three English neighbourhoods. Prog. Plan. 2012, 78, 101-150. [CrossRef]

40. Burinskiene, M.; Bielinskas, V.; Podviezko, A.; Gurskiene, V.; Maliene, V. Evaluating the significance of criteria contributing to decision-making on brownfield land redevelopment strategies in urban areas. Sustainability 2017, 9, 759. [CrossRef]

41. Collins, W.J.; Shester, K.L. Slum clearance and urban renewal in the United States. Am. Econ. J. Appl. Econ. 2013, 5, 239-273. [CrossRef]

42. Swope, C. The problematic role of public health in Washington, DC's, urban renewal. Public Health Rep. 2018, 133, 707-714. [CrossRef]

43. Devienne, E. Urban renewal by the sea: Reinventing the beach for the suburban age in postwar Los Angeles. J. Urban Hist. 2019, 45, 99-125. [CrossRef]

44. Qin, H.; Su, X. Urban Regeneration, 1st ed.; CITIC Press Group: Beijing, China, 2018; pp. 9-26.

45. Donaldson, R.; Du Plessis, D. The urban renewal programme as an area-based approach to renew townships: The experience from Khayelitsha's Central Business District, Cape Town. Habitat Int. 2013, 39, $295-301$. [CrossRef]

46. Tallon, A. Urban Regeneration in the UK, 2nd ed.; Tongji University Press: Shanghai, China, 2019; pp. $12-37$.

47. Yildiz, S.; Kivrak, S.; Arslan, G. Factors affecting environmental sustainability of urban renewal projects. Civ. Eng. Environ. Syst. 2017, 34, 264-277. [CrossRef]

48. Lai, L.W.C.; Lorne, F.T. Sustainable urban renewal and built heritage conservation in a global real estate revolution. Sustainability 2019, 11, 850. [CrossRef]

49. Zhou, W.; Xie, J. The inefficient land redevelopment in the organic renewal view: Wenzhou case. Planners 2014, 30, 203-207. (In Chinese)

50. Hao, P.; Sliuzas, R.; Geertman, S. The development and redevelopment of urban villages in Shenzhen. Habitat Int. 2011, 35, 214-224. [CrossRef]

51. Liu, G.; Yi, Z.; Zhang, X.; Shrestha, A.; Martek, I.; Wei, L. An evaluation of urban renewal policies of Shenzhen, China. Sustainability 2017, 9, 1001. [CrossRef]

52. Yi, Z.; Liu, G.; Lang, W.; Shrestha, A.; Martek, I. Strategic approaches to sustainable urban renewal in developing countries: A case study of Shenzhen, China. Sustainability 2017, 9, 1460. [CrossRef]

53. Liu, B.; Wang, X.; Xia, N.; Ni, W. Critical success factors for the management of public participation in urban renewal projects: Perspectives from governments and the public in China. J. Urban Plan. Dev. 2018, 144, 04018026. [CrossRef]

54. Xu, K.; Shen, G.Q.; Liu, G.; Martek, I. Demolition of existing buildings in urban renewal projects: A decision support system in the China context. Sustainability 2019, 11, 491. [CrossRef]

55. Zhuang, T.; Qian, Q.K.; Visscher, H.J.; Elsinga, M.G. Stakeholders' expectations in urban renewal projects in China: A key step towards sustainability. Sustainability 2017, 9, 1640.

56. Chan, E.H.W.; Lee, G.K.L. Contribution of urban design to economic sustainability of urban renewal projects in Hong Kong. Sustain. Dev. 2008, 16, 353-364. [CrossRef]

57. Peng, Y.F.; Qian, J.; Ren, F.; Zhang, W.H.; Du, Q.Y. Sustainability of land use promoted by construction-to-ecological land conversion: A case study of Shenzhen city, China. Sustainability 2016, 8, 16. [CrossRef]

58. Liao, Z. The evolution of wind energy policies in China (1995-2014): An analysis based on policy instruments. Renew. Sustain. Energy Rev. 2016, 56, 464-472. [CrossRef] 
59. Lv, X.; Niu, S.; Zhang, Q.; Zhong, T.; Chen, C. Evolution of policies on rural collective-owned construction land circulation in China based on content analysis method. China Land Sci. 2015, 29, 25-33. (In Chinese)

60. He, W.; Huang, X.; Zhong, T.; Zhao, Y.; Lv, X.; Tan, M. Evaluation of construction progress of the land supervision system based on content analysis. China Land Sci. 2013, 27, 4-10. (In Chinese)

61. Lv, X.; Niu, S.; Huang, X.; Zhao, Y.; Zhao, X.; Zhong, T. Policy evolution of economical and intensive use of land in China based on content analysis method. China Land Sci. 2015, 29, 11-18. (In Chinese)

62. Zhang, L.; Wang, C. A Sino-us comparison on public policy issues in urban planning. Urban Stud. 2011, 18, 33-38. (In Chinese)

63. Viney, L.L. The assessment of psychological states through content-analysis of verbal communications. Psychol. Bull. 1983, 94, 542-563. [CrossRef]

64. Kuang, B.; Lu, X.; Chen, D. Research on policy tool choices on crop rotation and fallow of cultivated land in China based on content analysis method. China Land Sci. 2018, 32, 30-36. (In Chinese)

65. Lin, Y.; De Meulder, B. A conceptual framework for the strategic urban project approach for the sustainable redevelopment of "villages in the city" in Guangzhou. Habitat Int. 2012, 36, 380-387. [CrossRef]

66. Lin, Y.; De Meulder, B.; Cai, X.; Hu, H.; Lai, Y. Linking social housing provision for rural migrants with the redevelopment of 'villages in the city': A case study of Beijing. Cities 2014, 40, 111-119. [CrossRef]

67. Liu, Z.M.; Zhang, L.; Rommel, J.; Feng, S.Y. Do land markets improve land-use efficiency? evidence from Jiangsu, China. Appl. Econ. 2020, 52, 317-330. [CrossRef]

68. Wang, J.; Fang, C. Growth of urban construction land: Progress and prospect. Prog. Geogr. 2011, 30, 1440-1448. (In Chinese)

69. Power, A. Does demolition or refurbishment of old and inefficient homes help to increase our environmental, social and economic viability? Energy Policy 2008, 36, 4487-4501. [CrossRef]

70. Zhao, J.; Yu, L. Research on the historical change of UK's land ownership and its influence. Urban Plan. Int. 2015, 30, 16-22. (In Chinese)

71. Greenstein, R.; Sungu-Eryilmaz, Y. Recycling the City: The Use and Reuse of Urban Land, 1st ed.; Lincoln Institute of Land Policy: Cambridge, MA, USA, 2004; pp. 61-62.

72. Chen, M.; Huang, Y.; Tang, Z.; Lu, D.; Liu, H.; Ma, L. The provincial pattern of the relationship between urbanization and economic development in China. J. Geogr. Sci. 2014, 24, 33-45. [CrossRef]

73. Liu, Y.; Zhang, J.; Li, C.; Zhou, G.; Fu, Z.; Liu, D. Influential intensity of urban agglomeration on evolution of eco-environmental pressure: A case study of Changchun, China. Chin. Geogr. Sci. 2017, 27, 638-647. [CrossRef]

74. Gao, Y.; Ma, Y. What is absent from the current monitoring: Idleness of rural industrial land in suburban Shanghai. Habitat Int. 2015, 49, 138-147. [CrossRef]

75. Nassauer, J.I.; Raskin, J. Urban vacancy and land use legacies: A frontier for urban ecological research, design, and planning. Landsc. Urban Plan. 2014, 125, 245-253. [CrossRef]

76. Lu, Z.L.; Liu, G.S.; Guo, M.; Zhu, X.X.; Wang, H.M.; Yi, L. Double-aspect method for identifying spatial patterns of inefficient land in inner-city Zhanjiang, China. J. Urban Plan. Dev. 2019, 145, 12. [CrossRef]

(C) 2020 by the authors. Licensee MDPI, Basel, Switzerland. This article is an open access article distributed under the terms and conditions of the Creative Commons Attribution (CC BY) license (http://creativecommons.org/licenses/by/4.0/). 